\title{
A non-destructive method based on the polymerase chain reaction for detection of hepatopancreatic parvovirus (HPV) of penaeid shrimp
}

\author{
C. R. Pantoja*, D. V. Lightner \\ The University of Arizona, Department of Veterinary Science and Microbiology, 1117 E. Lowell St., Bldg. \#90, Room 114, \\ Tucson, Arizona 85721, USA
}

\begin{abstract}
Current methods to detect hepatopancreatic parvovirus (HPV) infection of penaeid shrimp depend on invasive techniques that require dissecting the organs infected by this virus. However, sacrificing valuable stocks in order to determine their HPV status can be a drawback in the case of breeding programs. A method was developed for HPV detection by applying a polymerase chain reaction (PCR) assay to fecal samples collected from live HPV-infected shrimp Penaeus chinensis. A pair of PCR primers, $1120 \mathrm{~F} / 1120 \mathrm{R}$, which amplify a 592 base pair (bp) region from the virus genome, was designed from previously known HPV sequence information (HPV clone HPV8). PCR amplification with these primers generated a product of the expected size directly from the crude feces of HPVinfected shrimp but not from the feces of specific pathogen-free (SPF) shrimp. The HPV origin of the amplified product was validated by means of an in situ hybridization assay where the product of the amplification, labeled with digoxigenin (DIG)-11-dUTP, showed an intense reaction within hepatopancreatic cells displaying characteristic HPV lesions on HPV-infected shrimp. No reaction to this probe was observed when reacted in situ with sections of the hepatopancreas of SPF specimens or to sections of shrimp infected by the infectious hypodermal and hematopoietic necrosis virus (IHHNV), another parvovirus of penaeid shrimp. These primers were tested for specificity against homologous and nonhomologous viruses and no product was amplified. A fragment of the expected size was obtained only when purified HPV or purified HPV8 plasmid was used as template DNA. Under optimized conditions, these primers detected as little as $1 \mathrm{fg}$ of purified HPV8 plasmid DNA, equivalent to approximately 300 HPV particles. Analysis of fecal samples by PCR may prove useful for non-lethal screening of valuable shrimp of unknown HPV status. This same strategy also might be used for detection of other enteric viruses that infect penaeid shrimp.
\end{abstract}

KEY WORDS: Hepatopancreatic parvovirus (HPV) PCR · Penaeus chinensis

\section{INTRODUCTION}

Diagnosis of hepatopancreatic parvovirus (HPV) infection has been traditionally problematic. External signs of the disease are not specific for HPV and, frequently, diseased shrimp tend to be infected by other pathogens that may mask the actual effect of HPV infection (Flegel et al. 1992, Lightner 1993, Lightner et al. 1993). As a result, the most common method to ascertain the presence of this agent has been the examination of hematoxylin/eosin (H\&E)-stained histo-

\footnotetext{
•E-mail:cpantoja@u.arizona.edu
}

logical sections of the hepatopancreas, the main organ affected by this virus. Infection by HPV produces a characteristic cytopathic effect in the form of an intranuclear inclusion body that develops within Eand F-cells, mostly in the distal portion of the hepatopancreatic tubules (Lightner \& Redman 1985, Lightner et al. 1993, Lightner 1996). Analysis by transmission electron microscopy (TEM) is also useful in demonstrating the presence of HPV. However, the high cost and need for sophisticated equipment makes TEM impractical for routine diagnosis.

Detection of HPV infection can be accomplished by means of in situ hybridization with HPV-specific gene 
probes (Mari et al. 1995). This method is highly sensitive and useful in detecting low level infections but it is also an intrusive technique that requires the preparation of histological sections of the hepatopancreas.

An additional procedure for detection of HPV has been reported that uses Giemsa-stained smears of the hepatopancreas, which is more rapid and simpler than conventional H\&E or in situ hybridization (Lightner et al. 1993). Although this method does not demand the use of histopathology equipment, and can be used in field situations, it lacks sensitivity and also requires that the shrimp be sacrificed.

An alternative non-destructive approach to detect HPV is desirable because this would allow for the examination of shrimp without requiring the destruction of valuable stock during the process. In this regard, non-destructive detection of HPV through the examination of fecal samples is a feasible option. In the shrimp, nutrient digestion and absorption take place within the tubules of the hepatopancreas from where undigested material passes into the midgut to be later expelled in the form of a fecal pellet (Dall et al. 1990). Therefore, it is likely that, in a diseased shrimp, necrotic debris from HPV-infected hepatopancreatic cells can become mixed with undigested matter, reach the midgut, and become incorporated into the feces. Furthermore, HPV-infected cells, displaying characteristic intranuclear inclusion bodies, have been observed in the mucosal epithelium of the midgut and of the anterior midgut caecum of the shrimp (Lightner 1993). Hence, if viral particles are present in the cell debris originating from the hepatopancreas or the midgut epithelial cells, they may also be present in the feces, where they could be detected.

We present here a method, using PCR, by which HPV may be detected directly in fecal samples collected from HPV-infected shrimp.

\section{MATERIAL AND METHODS}

Shrimp species. A total of 10 juvenile Penaeus chinensis ( $0.9 \mathrm{~g}$ average weight) from an HPV-positive population that came from the Yellow Sea Fisheries Research Institute in China was used as a source of HPV contaminated feces. The shrimp were maintained in a 40 l glass aquarium, with artificial seawater (Marinemix, Marine Enterprises International, Inc., Baltimore, $\mathrm{MD}$ ) at $25 \mathrm{ppt}$ and $28 \pm 1^{\circ} \mathrm{C}$. Ammonia and nitrite were maintained at levels below $0.5 \mathrm{mg} \mathrm{l}^{-1}$ by using a preactivated biological filter.

A total of 10 juvenile specific pathogen-free (SPF; Lotz et al. 1995) Penaeus vannamei $1.0 \mathrm{~g}$ average weight) originating from the Oceanic Institute in Hawaii was used as a source of HPV-free feces. These shrimp were also maintained in a 40 l glass aquarium, under identical conditions as described for the HPVinfected shrimp.

The shrimp were fed daily with a commercial $35 \%$ protein diet (Rangen), at a rate of $6 \%$ of the biomass. Half of the ration was offered in the morning and the other half in the evening

Fecal sampling. The feces to be analyzed were collected from the bottom of the aquaria by using a plastic siphon and were drawn into a clean 1 l plastic beaker. Feces produced overnight were collected in the morning before feeding of the shrimp. All of the fecal material produced during the day was removed and discarded before the evening feeding. After collection by siphon, the feces were separated from food pellets not consumed during the night, small pieces of exuvia and other detritus. Only feces were transferred from the collection containers into sterile, $1.5 \mathrm{ml}$ microcentrifuge tubes. Tubes containing the feces were briefly centrifuged at low velocity $(2000 \times g)$ and the supernatant fluids discarded. Finally, the fecal pellets were stored at $-80^{\circ} \mathrm{C}$ until tested. To prevent cross-contamination, the aquaria with SPF shrimp and HPV-infected shrimp were kept in different rooms, and each day, the SPF tank was serviced and sampled before the HPV tank.

At the end of a $7 \mathrm{~d}$ sampling period, all of the shrimp were fixed for $48 \mathrm{~h}$ in Davidson's solution (AFA), transferred into $70 \%$ ethanol, and processed for H\&E histology and HPV in situ hybridization according to procedures previously described (Lightner 1996).

PCR primers and PCR conditions. A pair of PCR primers, $1120 \mathrm{~F}$ and $1120 \mathrm{R}$ (Table 1), was designated from sequence information previously generated from a HPV clone (clone HPV8; $2.136 \mathrm{kbp}$ insert) constructed with purified DNA from a Korean isolate of HPV (Pantoja \& Lightner unpubl.). The primers were selected using the Primer 2-Primer Designer Program Version 2.2 (Scientific and Educational Software, Stateline, PA) and synthesized by Genosys Biotechnologies, Inc., The Woodlands, TX. The size of the HPV fragment amplified by $1120 \mathrm{~F} / 1120 \mathrm{R}$ is $592 \mathrm{bp}$.

Optimized conditions for the use of these primers were: primers (50 pmol each), dNTPs (200 $\mu \mathrm{M}$ each), Ampli Taq Gold polymerase (2.5 U per $50 \mu$ l) (PE Applied Biosystems, Norwalk, CT), $\mathrm{MgCl}_{2}(4.0 \mathrm{mM})$, in PCR buffer (Tris-HCl, 10 mM; KCl, 50 mM, pH 8.3).

A master mix was prepared by including all of the reagents, except the template to be amplified, and was dispensed into PCR tubes in portions of $50 \mu \mathrm{l}$. After adding $0.5 \mu \mathrm{l}$ of template, the contents of the tubes were vortexed, and briefly centrifuged at low velocity. Finally, the samples were overlaid with $50 \mu$ l of mineral oil and subjected to 40 cycles in an automatic thermocycler (Perkin Elmer Cetus, Norwalk, CT) according to the following protocol: denaturation at $94^{\circ} \mathrm{C}$ for $1 \mathrm{~min}$; 
Table 1. Designation, sequence and characterization of the 2 oligonucleotide primers used in PCR amplification of HPV from the feces of HPV-infected Penaeus chinensis. Length of the product amplified is $592 \mathrm{bp}$

\begin{tabular}{|llcc|}
\hline Primer & Sequence $\left(5^{\prime}->3^{\prime}\right)$ & G/C ratio & $\mathrm{T}\left({ }^{\circ} \mathrm{C}\right)$ \\
\hline $1120 \mathrm{~F}$ & GGT-GAT-GTG-GAG-GAG-AGA & 55 & 58.5 \\
$1120 \mathrm{R}$ & GTA-ACT-ATC-GCC-GCC-AAC & 55 & 60.7 \\
\hline
\end{tabular}

5-bromo-4-chloro-3-indoyl phosphate (BCIP), supplied with the Genius I Kit.

Validation of the origin of the products amplified from the feces of HPV-infected shrimp. After collecting the fecal samples, all of the shrimp (SPF and HPV-infected) were fixed in Davidson's solution and processed for histological analysis according to protocols described previously (Lightner 1996). A series annealing at $60^{\circ} \mathrm{C}$ for $1 \mathrm{~min}$ i and polymerization at $72^{\circ} \mathrm{C}$ for $2 \mathrm{~min}$. Following the last cycle, the samples were polymerized for additional $7 \mathrm{~min}$ at $72^{\circ} \mathrm{C}$ and then kept for 5 to $10 \mathrm{~min}$ at $4^{\circ} \mathrm{C}$. A negative control, which used sterile distilled water instead of template, was included to monitor for possible contamination.

After amplification, the PCR solution was drawn off from beneath the oil layer of each sample and transferred to separate $1.5 \mu \mathrm{l}$ microcentrifuge tubes. Ten $\mu \mathrm{l}$ of sample from each tube was then analyzed in a $1 \%$ agarose gel stained with ethidium bromide $10.5 \mathrm{mg}$ $\mathrm{ml}^{-1}$ ), and visualized under UV illumination.

PCR specificity and sensitivity tests. To test the specificity of the $1120 \mathrm{~F} / 1120 \mathrm{R}$ primers, a series of reactions were carried out using as template either HPV purified from a cesium chloride gradient, purified infectious hypodermal and hematopoietic necrosis virus DNA (=IHHNV; Bonami et al. 1990), purified white spot syndrome virus DNA (=WSSV, a baculo-like virus of penaeid shrimp; Durand et al. 1997) or purified plasmid vector DNA (pGEM-T Easy, Promega Corporation, Madison, WI). The sensitivity of the assay was determined with 10 -fold dilutions of HPV8 plasmid DNA ranging from $10 \mathrm{ng}$ to $1 \mathrm{fg}$.

PCR assay to detect HPV in fecal samples. Feces $(0.02 \mathrm{~g})$ were taken from each daily sample and homogenized, separately, with $100 \mu$ of autoclaved $2 \%$ saline. The homogenized samples were boiled for $10 \mathrm{~min}$, quenched on ice for $1 \mathrm{~min}$, and centrifuged at $5000 \times g$ for $30 \mathrm{~s}$ at room temperature. Dilutions of each of the supernatant fluids were prepared $\left(10^{-1}, 10^{-2}\right.$, $10^{-3}$, and $10^{-4}$ ) with sterile distilled water. Purified HPV8 plasmid DNA was used as a positive control and sterile distilled water as a negative control.

Probe preparation. The 592 bp product amplified from the feces of HPV-infected Penaeus chinensis was electrophoresed in a $1 \%$ low melting point agarose gel, the band was excised and the DNA was purified by means of an agarase treatment (Boehringer Mannheim, Indianapolis, IN\}. Once extracted, the $592 \mathrm{bp}$ product was randomly labeled with digoxigenin (DIG)-11-dUTP using the Genius I Kit (Boehringer Mannheim, Indianapolis, IN) according to the manufacturer's protocol. Labeled DNA was visualized using alkaline phosphatase conjugated anti-DIG antibody and the reagents nitroblue tetrazolium (NBT) and of $4 \mu \mathrm{m}$ thick consecutive sections were placed onto Superfrost/Plus positively charged microscope slides (Fisher Scientific, Pittsburgh, PA). From each shrimp, one of the sections was stained with conventional H\&E (Lightner 1996) and the corresponding (consecutive) section was tested by in situ hybridization using the probe prepared with the products amplified from the feces of the HPV-infected shrimp. Consecutive sections were also prepared from specimens of IHHNV-infected shrimp: one section was stained with conventional H\&E and another subjected to in situ hybridization using the same HPV probe. An additional slide from the IHHNVpositive shrimp was also subjected to in situ hybridization with the IHHNV-specific gene probe BA401 (Mari et al. 1993). In situ hybridization procedures were according to those previously described by Lightner (1996).

\section{RESULTS}

\section{PCR specificity and sensitivity tests}

The primers $1120 \mathrm{~F}$ and $1120 \mathrm{R}$ amplified a region of the expected size (592 bp) only when purified HPV or purified plasmid DNA from clone HPV8 were used as a template in the PCR assay (Fig. 1). These primers

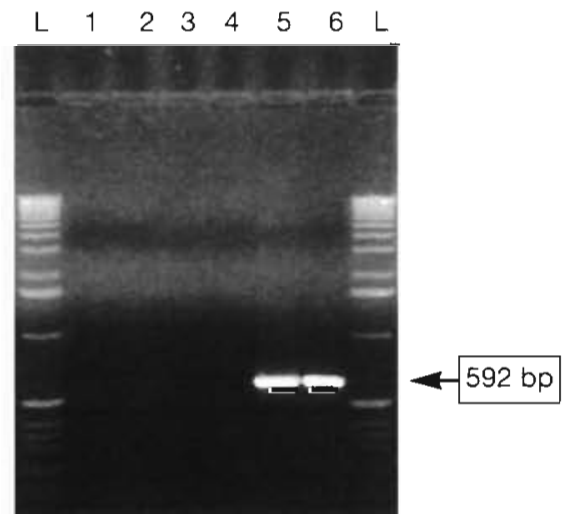

Fig. 1. Results of the specificity test with HPV primers $1120 \mathrm{~F} /$ 1120R. Amplification occurred only with HPV clone HPV8 (Lane 5) and purified HPV (Lane 6) templates. No amplification product was obtained with plasmid vector pGEM-T Easy (Lane 2), IHHNV DNA (Lane 3), and WSSV DNA (Lane 4). Lane 1: negative control without template. L: $1 \mathrm{~kb}$ DNA ladder (Gibco BRL) 


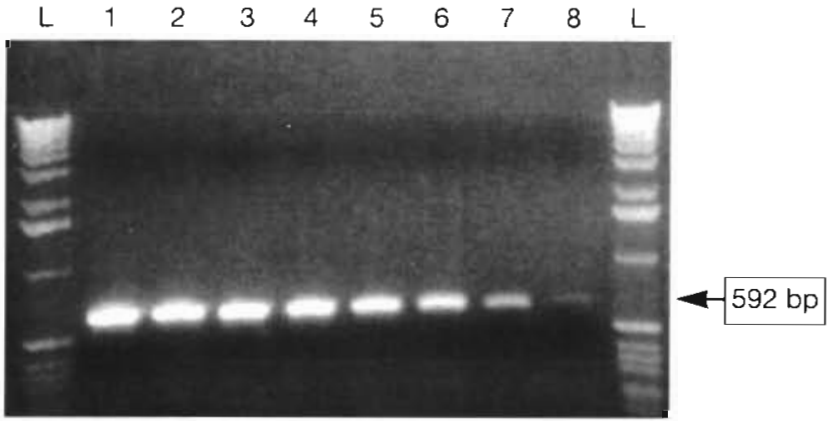

Fig. 2. Results of the sensitivity test with HPV primers $1120 \mathrm{~F} / 1120 \mathrm{R}$. Amplification product could be observed even at a dilution containing $1 \mathrm{fg}$ of purified HPV 8 plasmid DNA (Lane 8). Additional dilutions of HPV8 plasmid template tested were: $10 \mathrm{ng}$ (Lane 1), $1 \mathrm{ng}$ (Lane 2), $100 \mathrm{pg}$ (Lane 3), $10 \mathrm{pg}$ (Lane 4), $1 \mathrm{pg}$ (Lane 5), $100 \mathrm{fg}$ (Lane 6), and $10 \mathrm{fg}$ (Lane 7). L: $1 \mathrm{~kb}$ ladder (Gibco BRL)

did not generate products from purified IHHNV DNA, WSSV DNA, or pGEM-T Easy Vector DNA (Fig. 1). In the sensitivity test, the $1120 \mathrm{~F} / 1120 \mathrm{R}$ primers were able to generate a product of the expected size even at dilutions of template DNA (purified HPV8 plasmid DNA) down to $1 \mathrm{fg}$ (Fig. 2).

\section{PCR assay to detect HPV on fecal samples}

Amplification of the expected 592 bp fragment occurred in all of the samples where undiluted and diluted feces from HPV-infected shrimp served as a source of template DNA (Fig. 3). No amplification was obtained with the undiluted or diluted feces from SPF shrimp (Fig. 3). The results of the PCR assay agreed with those from the histopathological analysis of these

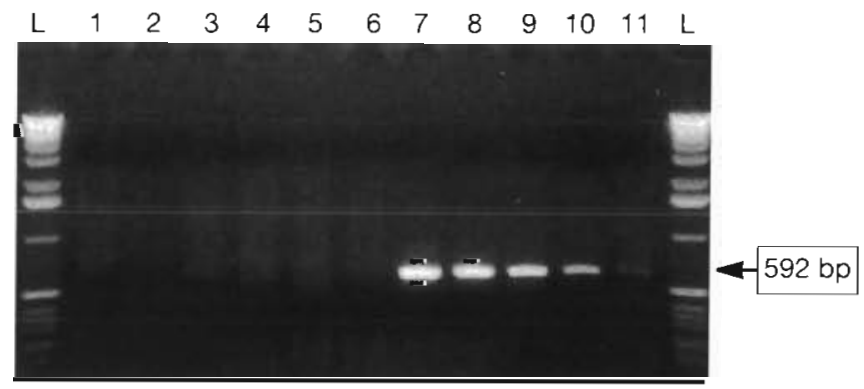

Fig. 3. Agarose gel showing amplification of the expected 592 bp product from undiluted template prepared with HPV feces (Lane 7) and from fecal template dilutions at $10^{-1}$ (Lane 8), $10^{-2}$ (Lane 9), 1. $0^{-3}$ (Lane 10), and $10^{-4}$ (Lane 11). No amplification was observed from the template prepared with undiluted SPF feces (Lane 2) and from SPF fecal template dilutions at $10^{-1}$ (Lane 3), $10^{-2}$ (Lane 4), $10^{-3}$ (Lane 5) and $10^{-4}$ (Lane 6). Lane 1: negative control without template. L: $1 \mathrm{~kb}$ ladder (Gibco BRL) shrimp. Conventional H\&E analysis showed characteristic HPV lesions within the hepatopancreas of 7 out of 10 Penaeus chinensis (70\% prevalence). Severity grade of HPV infection, as determined by conventional H\&E analysis (Lightner et al. 1993), ranged from low to moderate (Table 2). No HPV infection was detected by conventional H\&E in any of the SPF P. vannamei.

\section{Validation of the origin of the products amplified from the feces of HPV-infected shrimp}

The probe prepared by DIG labeling of amplified products from the feces of HPV-infected shrimp showed a strong positive reaction, as indicated by the deposition of a blue-black precipitate, within hepatopancreatic cells displaying characteristic HPV inclusions (Compare Fig. 4 a to 4 b). In total, 8 out of 10 Penaeus chinensis showed a positive reaction to this probe by in situ hybridization (Table 2). No reaction to this probe was observed for the IHHNV-infected shrimp (Fig. 4C) or the SPF specimens (not shown). The presence of IHHNV DNA in the IHHNV-infected shrimp was confirmed by the positive reaction to the IHHNV-specific gene probe BA401, which also indicates that the absence of reaction to the HPV probe was due to insufficient homology between probe and target and not to degradation of the IHHNV DNA.

\section{DISCUSSION}

Earlier attempts to detect HPV in shrimp feces included a dot blot hybridization strategy using a HPV-

Table 2. Prevalence and severity of HPV infection in Penaeus chinensis, as determined by conventional H\&E and in situ hybridization with the digoxigenin (DIG)-labeled HPV probe. The HPV probe was prepared with the products amplified by primers $1120 \mathrm{~F} / 1120 \mathrm{R}$ from the feces of HPV-infected $P$. chinensis. $\mathrm{ND}=$ not detected. $\mathrm{G} 1$ to $\mathrm{G} 4=$ severity grade of infection. $\mathrm{G} 1=$ low $_{;} \mathrm{G} 2=$ low to moderate $;$ G3 $=$ moderate ${ }_{i}$ $\mathrm{G} 4$ = severe

\begin{tabular}{|c|c|c|}
\hline \multirow[t]{2}{*}{ Specimen ID no. } & \multicolumn{2}{|c|}{ HPV status } \\
\hline & $\begin{array}{c}\text { Conventional } \\
\text { H\&E }\end{array}$ & $\begin{array}{l}\text { HPV in situ } \\
\text { hybridization }\end{array}$ \\
\hline A 1 & ND & ND \\
\hline A2 2 & $\mathrm{HPV}+(\mathrm{G} 1)$ & $\mathrm{HPV}+(\mathrm{G} 2)$ \\
\hline A3 & ND & $\mathrm{HPV}+(\mathrm{G} 1)$ \\
\hline A4 & $\mathrm{HPV}+(\mathrm{G} 2-3)$ & $\mathrm{HPV}+(\mathrm{G} 2-3)$ \\
\hline AS & $\mathrm{HPV}+(\mathrm{G} 2)$ & $\mathrm{HPV}+(\mathrm{G} 2)$ \\
\hline AG & $\mathrm{HPV}+(\mathrm{G} 1-2)$ & $\mathrm{HPV}+(\mathrm{G} 1-2)$ \\
\hline A7 & $\mathrm{HPV}+(\mathrm{G} 2)$ & $\mathrm{HPV}+\{\mathrm{G} 2\}$ \\
\hline A8 & ND & ND \\
\hline A9 & $H P V+(G 1)$ & $\mathrm{HPV}+(\mathrm{G} 2)$ \\
\hline A10 & $\mathrm{HPV}+(\mathrm{G} 2)$ & $\mathrm{HPV}+(\mathrm{G} 2-3)$ \\
\hline
\end{tabular}




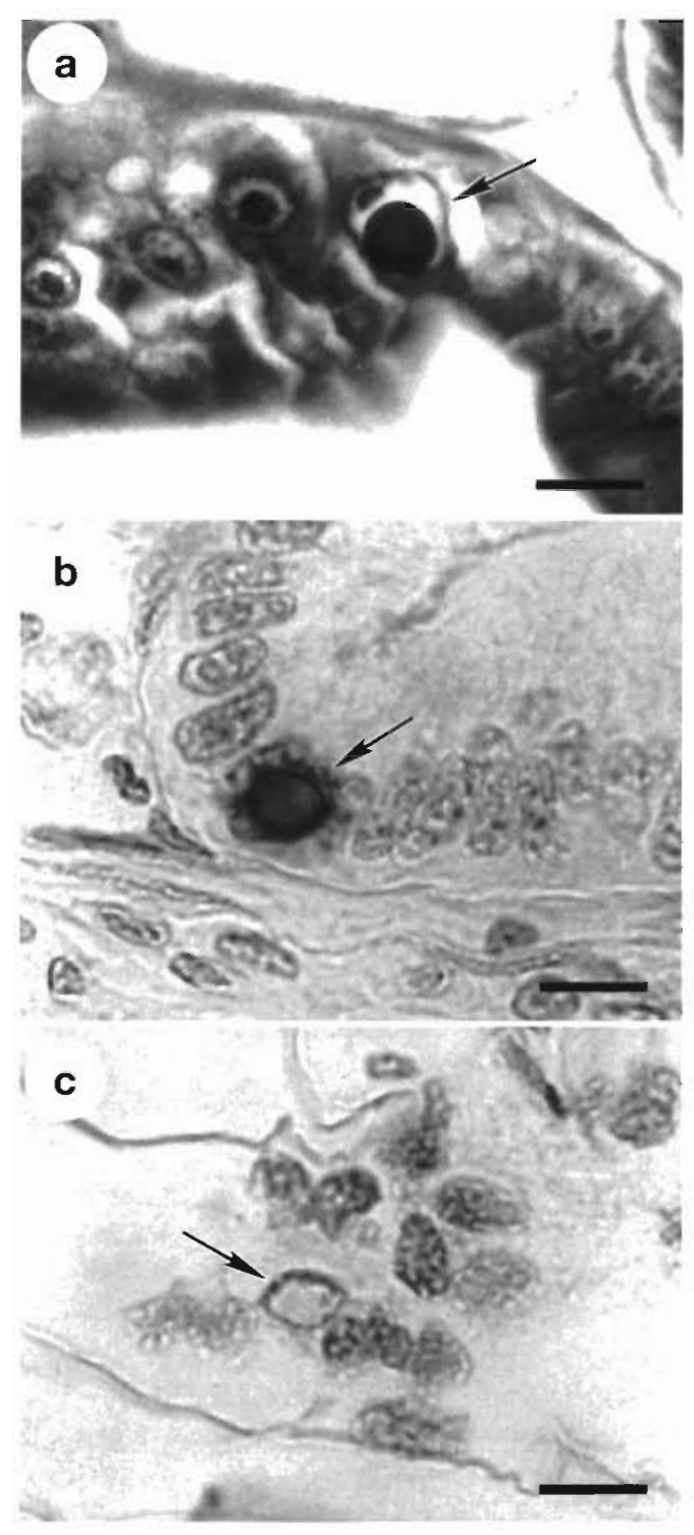

Fig. 4. (a) Characteristic HPV intranuclear inclusion body (arrow) showing peripheral displacement of the nucleolus. The infected cell is located within the tubular epithelium of the hepatopancreas of a HPV-infected juvenile Penaeus chinensis; H\&E stain. Scale bar $=10 \mu \mathrm{m}$. (b) Histological section, consecutive to the one shown in Fig. 4a, subjected to in situ hybridization with the digoxigenin (DIG)-labeled HPV probe prepared with the products amplified from the feces of HPVinfected $P$. chinensis. A strong positive reaction to the probe (black precipitate) can be observed within a HPV-infected tubule epithelial cell displaying a distinctive HPV intranuclear inclusion body (arrow). Bismarck brown counterstain. Scale bar $=10 \mu \mathrm{m}$. (c) Histological section, through the gill filaments of an IHHNV-infected Penaeus stylirostris, subjected to in situ hybridization with the DIG-labeled HPV probe prepared with the products amplified from the feces of HPV-infected $P$. chinensis. No reaction to the HPV probe (deposition of a black precipitate) was observed within characteristic IHHNV intranuclear inclusion bodies (arrow), or in any other tissues/organs of the shrimp (not shown). Bismarck brown counterstain. Scale bar $=10 \mu \mathrm{m}$ specific gene probe named SF2.0 (2.0 kbp; Mari et al. 1995). However, unidentified components in the fecal material had a tendency to react non-specifically with the probe, leading to false positive results and making it necessary to carry out time-consuming DNA extractions in order to eliminate the interference (Pantoja \& Lightner unpubl.). In contrast, the PCR procedure described above allows for the examination of fecal samples without having to extract DNA and provides specific and sensitive results faster than a dot blot hybridization assay.

The specificity of the primers $1120 \mathrm{~F} / 1120 \mathrm{R}$, designed from the HPV clone HPV8, was illustrated by the absence of amplification from related (IHHNV) or non-related (WSSV) viruses. The specificity of these primers was further validated by the results of the in situ hybridization assay performed with the probe prepared with the products amplified from HPVcontaminated feces.

Even at dilutions of $10^{-4}$ of the original sample, the concentration of viral particles in the feces of low to moderately infected shrimp was sufficient for detection by PCR. The results show that under the conditions established for this assay, the $1120 \mathrm{~F} / 1120 \mathrm{R}$ primers were capable of detecting as little as $1 \mathrm{fg}$ of HPV8 plasmid DNA, which is equivalent to approximately 300 HPV viral particles. This estimation is based on the similarity between the total length of plasmid HPV8 $(5.151 \mathrm{kbp})$, and the total length estimated for the HPV genome of approximately $5 \mathrm{kbp}$ (Bonami et al. 1995).

At this time it is not known with certainty the degree to which different geographic isolates of HPV may differ in their genomic sequences. Because of such a paucity of information, it is unknown if the HPV primers $1120 \mathrm{~F} / 1120 \mathrm{R}$ (developed from a Korean isolate of $\mathrm{HPV}$ ) can recognize other geographic isolates of HPV. The results from a comparative in situ hybridization study that employed the HPV-specific gene probe SF2.0 (also developed from a Korean isolate of HPV) suggested that genomic differences exist among some geographic isolates of this virus, and that some may not react with this probe (Lightner et al. 1994a). Furthermore, hepatopancreatic lesions, similar to those caused by HPV infection, have also been reported in the Malaysian prawn Machrobrachium rosenbergii. However, no reaction with the probe SF2.0 was observed during in situ hybridization assays, suggesting a lack of homology between the HPV-like virus from $M$. rosenbergii and that from Penaeus chinensis (Lightner et al. 1994b). Further testing of the $1120 \mathrm{~F} / 1120 \mathrm{R}$ primers will be necessary to demonstrate if they are capable of detecting other geographic isolates of this virus.

Another important point relates to the presence of substances in the feces and/or seawater that may have an inhibitory effect on the PCR assay. In order to sim- 
plify this study, and to determine the actual capacity of the PCR for detection of HPV in feces, an effort was made to exclude as many potential PCR inhibitors as possible. Such exclusion was based on the avoidance of organic build-up in the water, of chemical treatments to the water, or chemotherapeutic substances in the feed. However, in aquaculture situations, for example, the seawater in tanks or ponds may contain high levels of dissolved organic matter or detritus, or the shrimp may require treatment with medicated feed.

There is evidence that PCR inhibitors, such as humic acids and metals, must be removed from the sample water before attempting the detection of enteroviruses by PCR (Reynolds 1995, Marlowe at al. 1997). Therefore, the presence of possible PCR inhibitory substances in the feces, or the seawater from which fecal samples are collected, must be carefully evaluated before proceeding with the PCR assay.

Acknowledgements. This research was funded by the Gulf Coast Research Laboratory Consortium Marine Shrimp Farming Program, Cooperative State Research, Education, and Extension Service (CSREES), U.S. Department of Agriculture under Grant No. 95-38808-1424, the National Sea Grant Program, U.S. Department of Commerce under Grant No. NA56RG0617. The Mexican National Council of Science and Technology (CONACYT) provided financial support through a fellowship awarded to the first author to complete graduate studies at the University of Arizona. The shrimp stocks utilized in this study were kindly provided by $\mathrm{Mr}$ Jie Huang (HPV-infected Penaeus chinensis from the Yellow Sea Fishery Research Institute, Qingdao, Shangdong, China) and Mr Jim Sweeny (SPF P. vannamei from The Oceanic Institute, Makapuu Point, Hawaii).

\section{LITERATURE CITED}

Bonami JR, Trumper B, Mari J, Brehelin $M$, Lightner DV (1990) Purification and characterization of the infectious hypodermal and hematopoietic necrosis virus of penaeid shrimp. J Gen Virol 71:2657-2664

Bonami JR, Mari J, Poulos BT, Lightner DV (1995) Characterization of hepatopancreatic parvo-like virus, a second unusual parvovirus pathogenic for penaeid shrimp. J Gen Virol 76:813-817

Dall W, Hill BJ, Rothlisberg PC, Sharples DJ (1990) Physiology: digestion and assimilation. In: Blaxter JHS, Southward AJ (eds) Advances in marine biology, Vol 27. The biology of the Penaeidae. Academic Press, London, p $159-163$

Editorial responsibility: Timothy Flegel, Bangkok, Thailand
Durand S, Lightner DV, Redman RM, Bonami JR (1997) Ultrastructure and morphogenesis of White Spot Syndrome Baculovirus (WSSV). Dis Aquat Org 29:205-211

Flegel TW, Fegan DF, Kongsom $S$, Vuthikornudomkit $S_{\text {, }}$ Sriuraraitana S, Boonyaraptalin S, Chantanachookhin C, Vickers JE, MacDonald OD (1992) Occurrence, diagnosis and treatment of shrimp diseases in Thailand. In: Fulks W, Main KL (eds) Diseases of cultured penaeid shrimp in Asia and the United States. The Oceanic Institute, Makapuu Point, Honolulu, p 57-112

Lightner DV (1993) Diseases of penaeid shrimp. In: McVey JP (ed) CRC handbook of mariculture, Vol 1, 2nd edn. Crustacean aquaculture. CRC Press, Boca Raton, FL, p 393-486

Lightner DV (ed) (1996) A handbook of shrimp pathology and diagnostic procedures for diseases of cultured penaeid shrimp. Special publication of the World Aquaculture Society, Baton Rouge, LA

Lightner DV, Redman RM (1985) A parvo-like virus disease of penaeid shrimp. J Invertebr Pathol 45:47-53

Lightner DV, Redman RM, Moore DW, Park MA (1993) Development and application of a simple and rapid diagnostic method to studies on hepatopancreatic parvovirus of penaeid shrimp. Aquaculture 116:15-23

Lightner DV, Poulos BT, Bruce L, Redman RM, Nunan L, Pantoja C, Mari J, Bonami JR (1994a) Development and application of genomic probes for use as diagnostic and research reagents for the penaeid shrimp parvoviruses IHHNV and HPV and the baculoviruses MBV and BP. USMSFP 10th Anniversary Review, GCRL Special Publication No. 1, Ocean Springs, MS, p 59-85

Lightner DV, Redman RM, Poulos BT, Mari JL, Bonami JR, Shariff M (1994b) Distinction of HPV-type viruses in Penaeus chinensis and Machrobrachium rosenbergii using a DNA probe. Asian Fish Sci 7:267-272

Lotz JM, Browdy CL, Carr WH, Frelier PF, Lightner DV (1.995) USNSFP suggested procedures and guidelines for assuring the specific pathogen free status of shrimp broodstock and seed. In: Browdy CL, Hopkins JS (eds) Swimming through troubled water. Proceedings of the special session on shrimp farming, Aquaculture '95. World Aquaculture Society, Baton Rouge, LA, p 66-75

Mari J, Bonami JR, Lightner DV (1993) Structure and cloning of the genome of the IHHNV, an unusual parvovirus pathogenic for penaeid shrimp. Diagnosis of the disease using a specific probe. J Gen Virol 74:2637-2643

Mari J, Lightner DV, Poulos BT, Bonami JR (1995) Partial cloning of the genome of an unusual shrimp parvovirus (HPV): use of gene probes in disease diagnosis. Dis Aquat Org 22:129-134

Marlowe EM, Josephson KL, Miller RM, Pepper IL (1997) A method for the detection and quantitation of PCR template in environmental samples by high performance liquid chromatography. J Microbiol Methods 28:45-53

Reynolds KA (1995) Detection of enteroviruses in marine waters using RT-PCR. PhD dissertation. University of Arizona, Tucson, AZ

Submitted: May 12, 1999; Accepted: August 31, 1999

Proofs received from author(s): Jamuary 13, 2000 